\title{
The Syrphidae of Puerto Rico ${ }^{1,2}$
}

\author{
H. S. Telford ${ }^{3.4}$
}

One cannot state with certainty when the first syrphid was collected from Puerto Rico and adjacent islands. Fabricius described a number of

1 Manuscript submitted to Editorial Board October 30, 1972.

2 Scientific paper number 3914. College of Agriculture Research Center, Washington State University, Pullman, Washington. Work was conducted under Project No. 0046.

${ }^{3}$ Professor and Entomologist, Department of Entomology, Washington State University; Visiting Scientist, Department of Entomology, Agricultural Experiment Station, Mayagüez Campus, Río Piedras, Puerto Rico, September 1968-March 1969. This study was made possible by financial support from the Department of Entomology, Agricultural Experiment Station, Mayagïez Campus, University of Puerto Rico, Río Piedras. I wish to thank Dr. L. P. R. F. Martorell, formerly Chairman, Department of Entomology, Agricultural Experiment Station, especially for his support and aid in all aspects of the project. Mr. Silverio Medina Gaud, Associate Entomologist, Agricultural Experiment Station, was of considerable help. He accompanied me on almost all field trips, assisted in sorting and preparing the material and made valuable field trips on his own. Dr. J. R. Vockeroth, Entomology Research Institute, Ottawa, Canada, verified many determinations and offered advice on nomenclatural problems. Others who materially aided in the loan of specimens, verified determinations or in other ways were: Dr. George Drury, U.S. Atomic Energy Commission, El Verde-Caribbean National Forest, Puerto Rico; Dr. Y. S. Sedman, Western Illinois University; 1)r. I. V. Knutson, Systematic Entomology Laboratory, Agricultural Research Service, United States Department of Agriculture; Dr. P. W. Wygodzinsky, American Muscum of Natural History; Dr. John Lawrence, Museum of Comparative Zoology; Dr. Howard Weems, Florida Department of Agriculture; Dr. Frank M. Hull, University of Mississippi; Dr. M. T. James, Washington State University; Mr. Harold Oldroyd and Mr. Kenneth G. V. Smith, British Museum of Natural History; Dr. H. Frankhanel, Deutsches Entomologisches Institut; and Dr. George Miskimen, Ent omologist, formerly with the Entomology Pioneering Research Laboratory, now with the Department of Biology, Mayagüez Campus, University of Puerto Rico. Drs. J. R. Vockeroth, William J. Turner, and L. V. Knutson reviewed the manuscript. Miss Lynda $\mathrm{L}$. Richards prepared the illustrations.

${ }^{4}$ While this paper was in galley proof, the important and comprehensive publication, "A contribution to a generic revision of the Neotropical Milesinae (Diptera: Syrphidae)", Arq. Zool. S. Paulo 23(2): 73-215, 1972 by F. Cristian Thompson came to my attention. Although the milesines comprise only 17 of the 58 species occurring in Puerto Rico, this group is widely represented in the Neotropics, especially South and Central America. Any serious student of Neot ropical Syrphidae should refer to this valuable paper. 1)r. Thompson has made some drastic nomenclatural changes in some groups. For example, Copestylum Macquart is now recognized for all of the New World species of Volucella (ieoffroy except bombylans (L.) and Erislalis Latreille is partitioned into Erislalis s.s., Eoserislalis Kanervo and Palpada Macquart. Good generic keys have long been needed for the Neotropical genera and Dr. Thompson's contribution fills this void. 
species from the West Indies as early as 1781 (35). Von Roeder (78) published the first extensive list of Diptera from Puerto Rico, including several species of syrphids, based upon the collections of the Cuban naturalist, Dr. Juan Gundlach. Later workers who have contributed to our knowledge of the Puerto Rican syrphid fauna are Curran, Fluke, and especially Hull. Four publications are especially important: Curran (16) "Insects of Porto Rico and Virgin Islands"; Wolcott (107) "The Insects of Puerto Rico"; Fluke $(45,46)$ "Catalog of the Family Syrphidae in the Neotropical Region", and Maldonado and Navarro (72) "Additions and Corrections to Wolcott's 'Insects of Pucrto Rico' ".

As a result of synonymy, additional records and descriptions of four new species (Baccha (Ocyptamus) medina, B. (Ocyptamus) vockerothi, B. (Baccha) marotelli, and $B$. (Baccha) neoparvicornis), 58 species are now recorded from the island. Undoubtedly this list could be substantially increased if extensive collecting were continued. The present study was based largely upon the collection of the Department of Entomology at the Agricultural Experiment Station, University of Puerto Rico, Río Piedras, P.R. and to a lesser extent, on the collection of the Department of Biology, Mayagücz Campus, Mayagücz, P.R.

The collection at the Department of Entomology, Agricultural Experiment Station, in Río Piedras, was substantially increased by intensive Malaise trapping by myself and Mr. Silverio Medina Gaud during a 6month period from September 1968 to Narch 1969. The island was systematically collected and most of the typical ecological communities were sampled.

Additional records were obtained from Dr. George Drury of the U.S. Atomic Energy Commission, El Verde, Puerto Rico, from the collections of the U.S. National Museum of Natural History (USNM), the American Museum of National History (AMNH), and from the Canada National Collection (CNC). Unless otherwise stated all specimens are deposited in the collections of the Department of Entomology, Agricultural Experiment Station, University of Puerto Rico, Río Piedras, or in the M. T. James Entomological Collection, Washington State University, Pullman, Washington.

\section{ECONOMIC IMPORTANCE}

Of the 58 species herein recorded from the island, 41 may be aphidophagous. These include representatives of the genera Mesograpta, Baccha, Allograpta, Xanthandrus, and Parapenium. All of these except Parapenium belong to the Syrphinae. The remainder belong to the Milesiinac. The species of Mesograpta and Baccha outnumber, by far, all the other species of the family occurring on the island. It has long been assumed that most 
of the subfamily Syrphinae are aphidophagous; unfortunately, life history studies have been undertaken on only a few species. When more is known we may find that some are facultative predators or that some subsist entirely upon plant food. For example, the well-known predator Allograpta obliqua can live on plant food during its larval stages and Mesograpta polita has been reared on corn pollen. Representatives of other related genera, Melanosloma and Platycheirus, (not occurring in Pucrto Rico), can apparently survive on decomposing plant material as well as on insect prey.

Aphidophagous syrphids are often extremely beneficial in suppressing aphid outbreaks. A European species, Syrphus corollae, was observed devouring 680 aphids during its larval development (Láska, 61). The use of these predators should be more widely investigated. Unlike other insect predators such as coccinellids, syrphids produce and distribute large numbers of eggs over extensive areas even though prey density may be low. They are excellent fliers and range over extensive areas, thus can select favorable oviposition sites with developing aphid colonies (Sundy, 91). This is a considerable advantage in preventing aphid outbreaks.

\section{KEY TO GENERA OF SYRPHIDAE OCCURRING IN PUERTO RICO}

1. $r-m$ crossvein situated before middle of cell $\mathrm{M}_{2}$ (fig. 1) ....... 2 2

$r-m$ crossvein at or beyond middle of cell $M_{2} \ldots \ldots \ldots \ldots \ldots 10$

2. Humerus bare; arista usually bare; face tuberculate, usually at least partly yellow; usually with yellow abdominal bands; legs slender. . . . . .............................

Humerus pilose; either small (5-6 mm.), bluish-black with bare arista, or larger more robust species with plumose arista and face

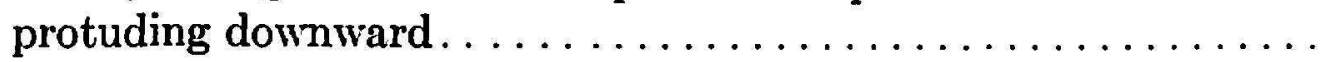

3. $M_{1}+{ }_{2}$ not recurrent distally; face protruding downward, arista moderately to densely plumose......................

$\mathrm{M}_{1+2}$ not recurrent; face not protracted, arista bare; small (5-6 $\mathrm{mm}$.), bluish-black species with short white pile... Parapenium

4. Large (8-19 mm.), brightly metallic-green, blue or bluish-green or

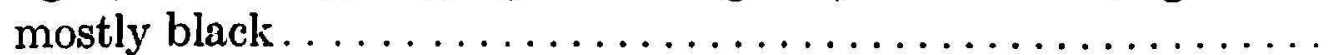

Smaller $(\bar{j}-6 \mathrm{~mm}$.$) , brown and black or black and yellow$

Volucella

5. Brightly metallic-green, blue or bluish-green; face with tubercle each side of median tubercle; $(8-12 \mathrm{~mm}$.).......... Ornidia Mostly black; basal half of wing blackish or dark-brown on anterior half; face without tubercules; large robust species; (16-19 mm.)

Volucella

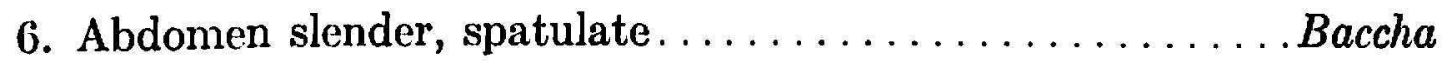
Abdomen broader with parallel sides................... 
7. Mesonotum with anterior collar of longer hairs.........Baccha Mesonotum without longer hairs anteriorly.............. 8

8. Face and scutellum entirely black or dark blue.....Xanthandrus Face and scutellum partly or entirely yellow................

9. Face vertical, with obscure tubercle; mesonotum with disc shining black.............................. Allograpta

Face distinctly protruding below; mesonotum with cinereous stripe

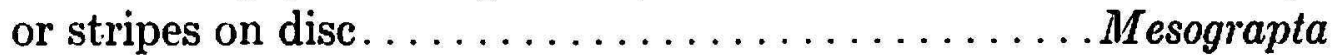

10. Vein $R_{4+5}$ deeply bent into cell $R_{5}$; hind femur not enlarged. ..... 11 Vein $R_{t+5}$ straight or nearly so; hind femur enlarged, spinose along lower surface. . . . . . . . . . . . . . . . . . . . . . 12

11. Yellow or gray markings on mesonotum composed of dense tomen-

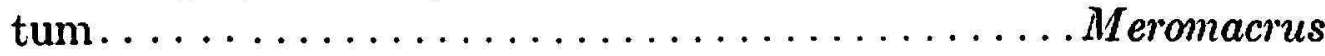

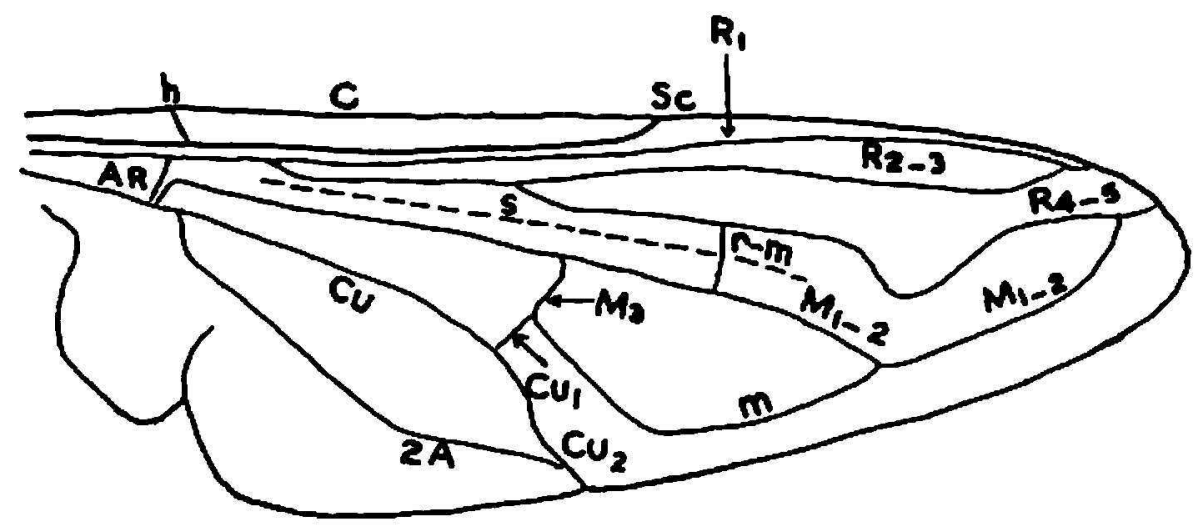

FIG. 1.-Wing of Erislalis showing venation.

Yellow or gray markings of mesonotum due to either ground color or to pollen. . . . . ................... Eristalis

12. Face concave in profile, at most weakly carinate; metasternum

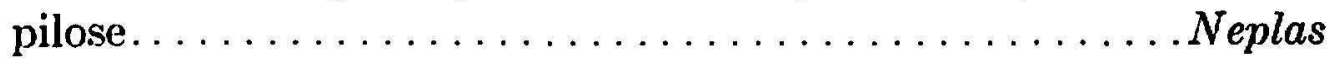

Face not concave, strongly carinate; metasternum pubescent or bare. Crepidomyia

\section{Genus Allograpta Osten Sacken}

Allograpla Osten Sacken 1876: 49 (76) (Type obliqua Say).

References: Curran $(15,16,23,26)$; Flukc (42).

The larva are believed to be aphidophagous.

\section{KEY TO SPECIES}

Squama mostly brown; front of male black pilose ..... . limbata (Fabricius) Squama yellowish, at most slightly infuscated; front of male usually almost all yellow pilose......................... venusia Curran 


\section{Allograpta limbata (Fabricius)}

Scaeva limbata Fabricius 1805: 251, (39).

Allograpta fuscisquama Curran 1927: 4, (15) (NEW SYNONYM).

Wolcott (107) apparently was the first to suggest that Curran's fuscisquama was synonymous with limbata. Dr. J. R. Vockeroth examined two o syntypes of limbata in Copenhagen and sent me a sketch of the addomen of one of them. This illustration compared favorably with Curran's description of his type. In addition, Dr. Vockeroth wrote me that limbala keys to fuscisquama in a manuscript key which he prepared with Curran's types of both fuscisquama and venusta before him.

This species is fairly common. I have examined specimens from Corozal, El Verde, Aguas Buenas, Caja de Muertos Island (south of Puerto Rico), Isabela, Río Piedras, Barranquitas, Mayagüez, EI Yunque, and Cayey.

\section{Allograpta venusta Curran}

\section{Allograpta venusta Curran 1927: $\overline{5}$, (15).}

Wolcott (107) stated that C. T. Greene identified some specimens of Allograpta from the island as limbata Fabricius. The material at Río Piedras bearing Greene's label contained only one damaged specimen which resembled venusta. There was a series of 19 additional specimens with a single typed label of limbata. These also were venusta, not limbata as labelled. Additional Malaise-collected material came from Castañer, Corozal and Cayey.

\section{Genus Mesograpta (Loew)}

Mesogramma Loew 1866a: 157 (preoc.) (67).

Mesograpta Loew 1872: 114, (69) (Type parvula Loew).

Mitrosphen Enderlein 1938: 227, (33).

Antiops Enderlein 1938: 228, (33).

Hybobathus Enderlein 1938: 233, (33).

References: Williston (101,103); Curran (16,18,24); Hull (53); and Fluke (44) (Syn.).

Unfortunately little is known about the biology of this large group of syrphids. It is generally believed that the larvae are aphidophagous. However, only the feeding habits of polita (Say) are known and it feeds on corn pollen.

This genus is in a state of confusion, principally because taxonomists have relied too heavily upon highly variable color patterns. I have not attempted to present a key to the species. A critical study should be undertaken based upon genitalia or other morphological characters to scparate the species. 


\section{Mesograpta arcifera Loew}

Mesograpta arcifera Loew 1866 a: 160, (67).

This species is one of the most abundant syrphids in Puerto Rico.

\section{Mesograpta aurulenta Williston}

Mesograpta aurulenta Williston 1887: 102, (101).

Mesogramma ruficincla Curran 1927: 7, (15) (NEW SYNONYM).

I have compared Curran's type with a $\sigma^{7}$ and $q$ from Williston's type series (San. Dom. Acc. 19, 702, Williston) from the USNM and I believe the two specimens are conspecific. In Curran's type the black annula are confined to the hind legs. In the Williston material the posterior leg of the $\sigma^{7}$ appears mostly black as do the femur, tibia, and tarsus of the middle and anterior femora. In the $q$ the black coloring is less prominent, especially on the anterior femur.

This species appears to be quite rare. Wolcott (107) recorded it only from Aibonito and El Yunque. Some of his specimens from Aibonito are in the Rio Piedras collection.

\section{Mesograpta basilaris (Wiedemann)}

Syrphus basilaris Wiedemann 1830: 143, (100).

Mesogramma soror Schiner 1868: 350, (87).

Mesograpta variabilis Wulp 1883: 26, (108).

Mesogramma bidentata Williston 1891: 25, (103).

Mesogramma diversa Giglio-Tos 1892: 3, (48).

Mesogramma basilaris flavocuneus Hull 1940: 433, (50).

Mesogramma basilaris bifida Hull 1943a: 25, (53).

Mesogramma basilaris neotropica Hull 1943a: 14,36, (53).

A paratype $\%$ of Hull's neotropica and a $\sigma^{7}$ determined as basilaris by Hull from the USNM were examined as well as the badly damaged type in the BMNH. They closely resemble floralis (Fab.). It is possible that floralis and basilaris are conspecific. I saw no specimens from Puerto Rico which I could assign to this species, although Wolcott (107) stated that C. L. Metcalf determined material as this species from Coloso, Manatí and Point Cangrejos (Punta Cangrejos).

\section{Mesograpta boscii (Macquart)}

Syrphus boscii Macquart 1842: 100, (70).

Syrphus gurges Walker 1852: 236, (98).

I have seen no specimens of boscii from Puerto Rico although Wolcott (107) quoted von Roeder as having determined this species from the island. 


\section{Mesograpta difficilis (Curran)}

Mesogramma difficilis Curran 1930b: 6, (18).

Curran described this species from eight specimens, from Puerto Rico (Coamo Springs, Caguas, Adjuntas, Manatí, Corozal, Aibonito) and one from Tumatumari, British Guiana. I examined one damaged $\sigma^{T}$ paratype from Manati (AMNH). Curran believed the species to be related to duplicata Wiedemann and vatsoni Curran.

\section{Mesograpta duplicata (Wiedemann)}

Syrphus duplicalus Wiedemann 1830: 142, (100).

Syrphus orchrogaster Thomson 1869: 494, (95).

This species was fairly common and frequently taken in Malaise traps. The localities include: Ciales, Guavate, Corozal, Isabela, Gurabo, Aguas Buenas, Proyecto Vázquez, Cayey, Barranquitas, Castañer, Arecibo, Aibonito and Caguas.

\section{Mesograpta floralis (Fabricius)}

Scaeva floralis Fabricius 1798: 563, (38).

Mesogramma flamminea Hull 1941: 312, (51).

This species is possibly the most common syrphid in Puerto Rico. Thousands of individuals can be taken in a few days collecting by swceping or with a Malaise trap (fig. 2). It is highly variable in color. There may be a complex of species.

\section{Mesograpta laciniosa Loew}

Mesograpta laciniosa Loew 1866a: 159, (67).

This species is well-defined and quite common.

\section{Mesograpta minuta (Wiedemann)}

Syrphus minutus Wiedemann 1830: 146, (100).

I have seen no specimens from Puerto Rico. Curran $(16,18,24)$ and Hull (53) did not mention this species. Fluke $(45,46)$ recorded it only from Brazil and Cuba. However Wolcott (107) stated “... is listed by Dr. Gundlach as a Mesograpta 'rara en Pucrto Rico'".

\section{Mesograpta musica (Fabricius)}

Scaeva musica Fabricius 1805: 253, (39).

This specics is quite common and has been collected from numerous localities. 


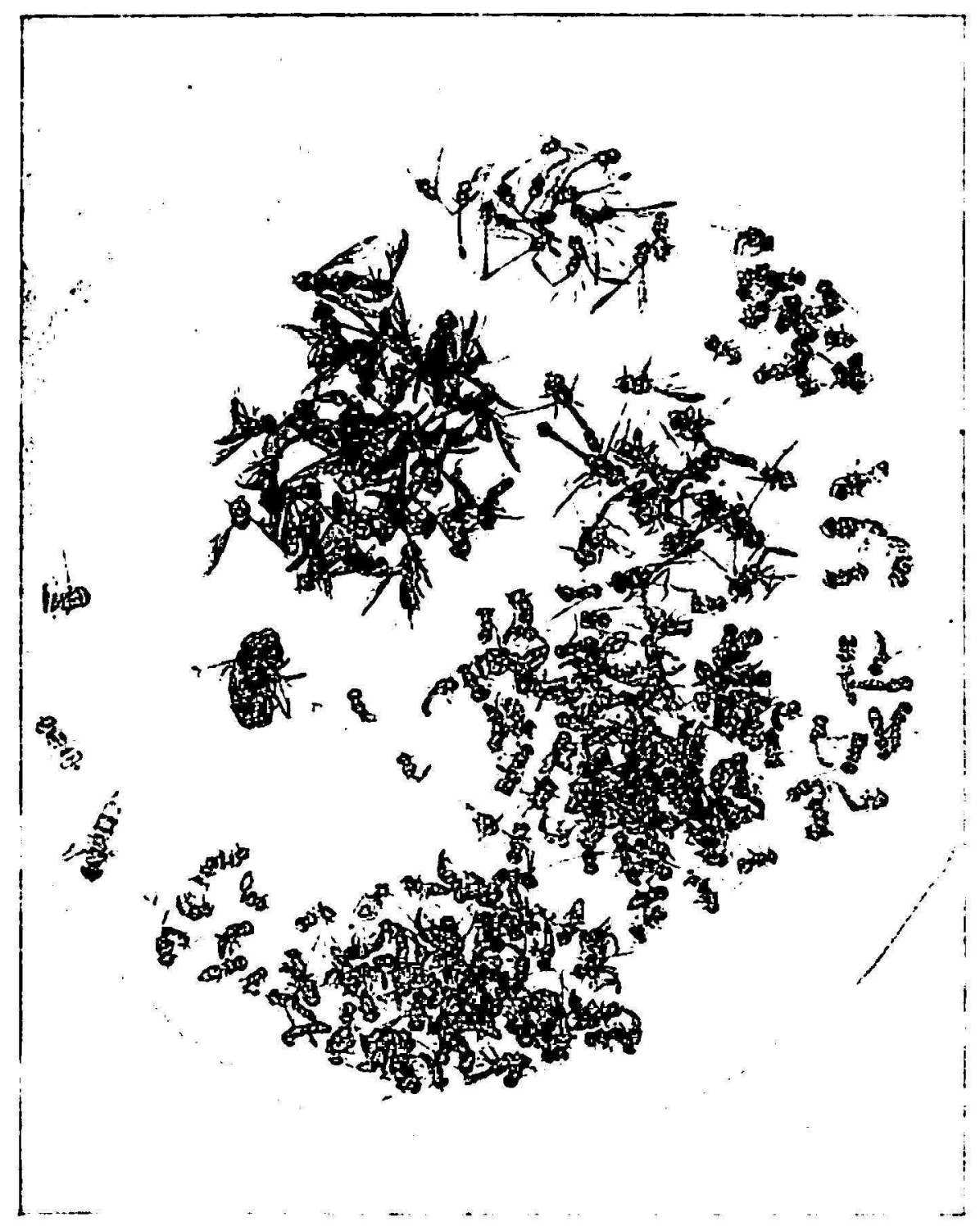

FIG. 2.-A single 2t-hour collection of syrphids from a Malaise trap. Primarily Baccha latiuscula (Loew), clavala (Fab.), deceplor (Curran), and Mesograpta spp. The large specimen is Oruidia obesa (Fab.)

\section{Mesograpta picta (Macquart)}

Syrphus piclus Macquart 1842: 99, (70).

Mesogramma poecilogastra Loew 1866a: 159, (67).

I have records from Arceibo, Mayagüez, El Verde-Caribbean National Forest, Proyecto Vázçuez, Cidra, lortuna, Curabo, Caycy, Castañer, Isabela and Corozal.

\section{Mesograpta polita (Say)}

Scaeva polita Say 18:23: 88, (85).

Syrphus cingulatulus Macquart 1850: 459, (71). 
Syrphus hecticus Jaennicke 1867: 398, (58).

I have records from Arecibo, Castañer, Corozal, Mayagüez, Río Piedras, Aibonito, Lajas, Guavate, Isabela, and Gurabo.

\section{Mesograpta rufocincta (Curran)}

Mesogramma rufocincla Curran 1927: 7, (15).

Dr. W. W. Wirth determined this species from Puerto Rican material now in the USNM (Maldonado and Navarro, 72).

\section{Mesograpta subannulata Loew}

Mesograpta subannulata Loew 1866a: 157, (67).

Although Wolcott (107) stated that this species is fairly common, I did not collect representatives nor was it represented in the collections at Rio Piedras or Mayagüez. Two specimens from Arecibo and Arroyo were examined in the USNM, identified as this species by Dr. L. V. Knutson. They resemble floralis (Fabricius) and quite likely belong to this complex. In fact Curran (11) once believed the two were conspecific.

\section{Mesograpta verticalis (Curran)}

Mesogramma verticalis Curran 1927: 6, (15).

Curran described this species from a single male from Cayey. I have seen specimens from Castañer, Arecibo, Cayey, Mayagüez, Guavate, Proyecto Vázquez, Gurabo, and Río Piedras.

\section{Mesograpta violacea (Curran)}

Mesogramma violacea Curran 1926a: 103, (13).

Mesogramma luna Hull 1943a: 21 (53) (NEW SYNONYM)

This species was described by Curran from a unique $\sigma^{7}$ from Jamaica. The type of violacea was loaned to me from the BMNH through the courtesy of Kenneth G. V. Smith and compared with Puerto Rican material. Hull (53) stated that this holotype of luna was in the USNM. However, Dr. Lloyd Knutson wrote me as follows: " . . there is a male of $M$. luna in the main collection labeled 'Mango bloom, Mayagüez, P.R. Mar. 14.33; A. G. Harley Colr; San Juan no. 3816; Paratype; Mesogramma extrapolata Hull.” Dr. Wirth, at some time, added the following label, 'This specimen should probably be the holotype of Mesogramma luna Hull 1943.' I think we would be safe in assuming that the 'Mesogramma extrapolata Hull' label got on this specimen by mistake, and that it is either the holotype of M. luna, or the paratype cited by Hull. Your 3 specimens... (from Puerto Rico) are certainly the same species." 
A $\sigma^{7}$ and $o$ were collected in coitu from El Verde Caribbean National Forest by Mr. Medina which clearly associates the $q$ with Curran's species. This species is quite common.

\section{Genus Baccha Fabricius}

Baccha Fabricius 1805: 199, (39) (Type elongatus Fabricius).

Bacchina Williston 1896a: 86, (105).

References: Williston (101); Curran (16,17,21,24,28,29), and Hull $(54,56,57)$. The larvae are mostly aphidophagous but some are especially predaceous upon coccids.

\section{KEY TO SPECIES}

1. Epistoma projecting beyond antennal base; scutellum margined anteriorly and posteriorly with yellow........ clavata (Fabricius) lace retreating below tubercle; if tubercle lacking, face gently convex............................. 2

2. Wing glossy hyaline with conspicuous apical spot; mesonotum shiny-black with 3 narrow light-grey vittae; abdominal tergites -25 gray vittate and with oblique side spots; 4-6 mm.

ornatipes Curran

Although apical wing spot may be present, mesonotal and abdominal markings not as above.................. 3

3. Face tuberculate............................. 5

Fact not tuberculate ....................... 4

4. Wing with a definite apical spot, infuscated along costal margin and just anterior to anterior crossvein.......... incompta Austen Wing of $\sigma^{7}$ with light-brown uniform infuscation, wing of $\%$ hyaline; front of both sexes with minute transverse striations

graciles Williston

5. Large (10-16 mm.); mesonotum with three broad yellow vittac narrowed posteriorly; $R_{5}$ vein slightly curved into $R_{5}$ cell

capitata Loew

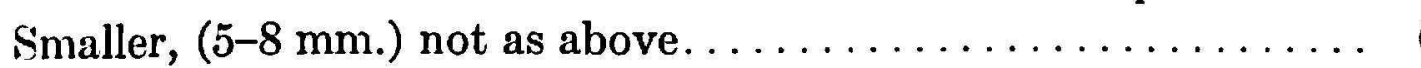

6. Thorax and abdomen shiny steel blue, latter flattened, subspatulate;

1st abdominal tergite with pilose, pale-yellow tubercle laterally, tergites $2,3,4$, with narrow yellow lateral diagonal rectangular markings; 5 th tergite with reduced to small lateral yellow spots medina n. sp.

7. Not as abovetum with definite anterior collar of white or yellow hairs; 
abdomen not distinctly petiolate, sides often subparallel; inner portion of 2nd antennal segment extending into 3rd segment anteriorly. ................................. 8

Mesonotum without definite anterior row of hairs; abdomen often petiolate; antenna not as above.................. 14

8. Wing uniformly brownish either only at base or over almost entire

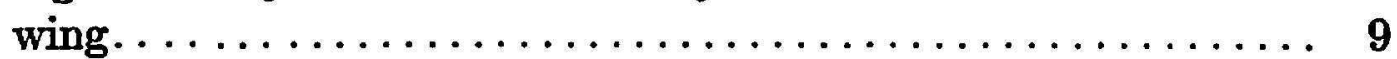

Wing brown with well defined hyaline maculated areas........ 11

9. Scutellum dull brownish-yellow.............. scutellata (Loew) Scutellum black or brownish-black.................. 10

10. Basal half of wing uniformly brownish, outer half hyaline dimidiata (Fabricius)

Most or all of wing uniformly brown; abdomen metallic blue latiuscula (Loew)

11. Face yellow grey with brownish tubercle; pleuron with long yellowwhite pile........................ fasciata Roeder Face unicolorous, although tubercle may be slightly darker; pleuron bare or almost bare. . . . . . . . . . . . . . . . . . . . 12

12. Face light-brown or reddish-brown........... fascipennis Say Face yellow, almost translucent................... 13

13. Abdominal tergites brownish; wing mostly hyaline with brown maculations...................... vockerothi $\mathrm{n}$. sp. Abdominal tergites violaceous or steel blue; wing predominantly brown...............conformis (Loew), cylindrica (Fabricius)

14. Pleuron largely yellow. .......................... 15

Pleuron mostly black. ........................ 18

15. Wing uniformly tinged with brown, darker only along costal area... 16

Wing hyaline, except brownish costal area and often with dark spot at tip................................. parvicornis Loew

16. Second abdominal tergite with broad yellow band.... rica Curran With no such band.......................... 17

17. Sternopleuron mostly brownish-black...........cubana Hull Sternopleuron yellow................ neoparvicornis $\mathbf{n}$. sp. 18. Face yellowish along margins, tubercle brownish; forelegs mostly yellow; abdomen threadlike..............deceptor Curran Face black; forelegs mostly black; abdomen subspatulate martorelli $\mathrm{n} . \mathrm{sp}$.

\section{Baccha (Mimocalla) capitata Loew}

Baccha capitata Loew 1863: 14, (66).

Only three specimens were examined. Two were from Vega Alta and 
Comerío in the collection at Río Piedras. One from Mayagüez is in the Mayagüez collection.

\section{Baccha (Dioprosopa) clavata (Fabricius)}

Syrphus clavatus Fabricius 1794: 298, (37).

Baccha babista Walker 1849: 549, (97).

Baccha facialis Thomson 1869: 504, (95).

Conops? quadrimaculatus Ashmead 1880: 70, (1).

Spazigaster bacchoides Bigot 1883: 326, (7).

This species was particularly abundant. Over 200 specimens were t,aken within a few days from a Malaise trap located at Isabela.

\section{Baccha (Ocyptamus) conformis (Loew)}

Ocyptamus conformis Loew 1866b: 38, (68).

I have examined no specimens from Puerto Rico and there is some doubt that this species occurs here. It is omitted in Hull (54) and in Curran $(16,17,24,28,29)$. Hull (56) mentioned $B$. conformis but did not include it in his key. However, Wolcott (107) credited Dr. Juan Gundlach and Mr. R. $\mathrm{H}$. Van Zwaluwenburg as having collected it on the island. Fluke $(45,46)$ recorded it from Cuba. This species is allied to cylindrica.

\section{Baccha (Baccha) cubana Hull}

Baccha cubana Hull 1944: 30, (55).

This is apparently a new record for Puerto Rico. Three specimens were determined from Cayey, Arecibo and El Verde-Caribbean National Forest.

\section{Baccha (Ocyptamus) cylindrica (Fabricius)}

Syrphus cylindricus Fabricius 1781: 249, (35).

Ocyptamus fascipennis Wulp 1883: 9, (108).

Ocyptamus fuscipennis Williston (in part) 1887: 119, (101).

This species is quite common. I examined specimens from Cayey, El Verde-Caribbean National Forest, Río Piedras, Proyecto Vázquez, Fortuna, Mayagüez, Mona Island (west of Puerto Rico), Salinas, Lajas, Isabela, Corozal, Guavate, Caja de Mucrtos Island (south of Puerto Rico), and Yauco. In addition, the Mayagüez collection contained specimens from Mayagüez, Adjuntas, Coamo, Ponce, Aguadilla, Las Marías, and Lares.

\section{Baccha (Baccha) deceptor Curran}

Baccha deceptor Curran 1930a: 14, (17).

Baccha stenogaster Williston 1888: 266 (Curran), (102). 
Curran (16) recorded $B$. slenogaster from Puerto Rico. Later, (21) he stated: "These ( $B$. deceptor) are the specimens recorded in my paper on the 'Diptera of Porto Rico and Virgin Islands' as B. stenogaster Williston. A comparison with Williston's type, which was from Brazil, shows that the West Indian form is quite distinct." This is a common species collected from many localities.

\section{Baccha (Ocyptamus) dimidiata (Fabricius)}

Syrphus dimidiatus Fabricius 1781: 234, (35).

Pipiza divisa Walker 1857: 156, (99).

Pipiza dolosa Walker 1857: 156, (99).

Although both Curran (15) and Wolcott (107) recorded this species from a number of localities, only four specimens from Mayagüez, Isabela, Fortuna, and Arecibo were seen. This species closely resembles latiuscula (Loew). Hull (56) separated the two principally on the amount of wing infuscation. The specimens from Mayagüez and Isabela showed some intergradation. If large series were examined these species may all prove to be conspecific.

\section{Baccha (Ocyptamus) fasciata Roeder}

Baccha fasciata Roeder 1885: 342, (78).

There has been some confusion about the identity of this species. Wolcott (107) stated " . . . described from Puerto Rico by Herr Victor von Roeder (1885-342), the type collected by Dr. Gundlach ...." Although fasciata was mentioned once by Hull (56), he did not include it in his key. Curran (16) made no reference to it. A number of specimens determined as fasciata were in the collection at Río Piedras. These and additional specimens collected by Mr. Medina and myself keyed down to cylindrica (Fab.). Dr. J. R. Vockeroth loaned me a $\sigma^{7}$ specimen from the CNC (RS80, Puerto Rico, J. W. Boyes) which undoubtedly is this species.

\section{Baccha (Ocyptamus) fuscipennis Say}

Baccha fuscipennis Say 1823: 100, (85).

Syrphus peas Walker 1849: 590, (97).

Syrphus amissas Walker 1849: 589, (97).

Syrphus radaca Walker 1849: 590, (97).

Ocyptamus longiventris Loew 1866b: 38, (68).

I have examined no specimens from the island. Wolcott (107) stated that Greene determined fuscipennis from material collected from Palo Seco and Dorado. Greene may have confused fuscipennis with $B$. vockerothi new species. 


\section{Baccha (Leucopodella) gracilis Williston}

Baccha gracilis Williston 1891: 34 (103).

Only one specimen was previously recorded from Puerto Rico (Curran) (16). I identified additional material from El Yunque, Cayey and El Verde-Caribbean National Forest as well as a specimen from Adjuntas (USNM).

\section{Baccha (Leucopodella) incompta Austen}

Baccha incompta Austen 1893: 147, (2).

Curran (16) identified three specimens from Adjuntas. Mr. Medina and I collected additional specimens which I have identified as incompta from Proyecto Vázquez, El Verde-Caribbean National Forest and Aguas Buenas

\section{Baccha (Ocyptamus) latiuscula (Loew)}

Ocyptamus latiusculus Loew 1866b: 39, (68).

This species was quite abundant.

\section{Baccha (Ocyptamus) loewi Sedman}

Ocyptamus scutellata Loew 1866b: 39, (68) (preoc.). Baccha (Ocyptamus) loewi Sedman 1965: 573 (in Stone et al, 1965, (90).

Maldonado and Navarro (72) stated that Wirth determined this species from material taken at Mayagüez (USNM).

\section{Baccha (Baccha) martorelli new species (Fig. 3)}

This is a relatively small, delicate, shining steel blue and opaque black species with mostly clear wings, appearing infuscated only on the subcostal cell. It keys to near shropshirei Curran in Hull (56), but in Curran's species the basal portion of the wing is dark. Length of body of holotype, $5 \mathrm{~mm}$.

Female: Head: Face steel blue, broad grey pollinose band along margin, tubercle broad, protruding to antennal base. Front, sparsely white pilose, steel blue with narrow lateral pollinose bands. Occiput grey pollinose with row of white pile projecting backward.

Thorax: Notum shiny steel blue with two vittae narrowed posteriorly spare grey pile, except definite row anteriorly, broad suboval opaque black spot anterior to scutellum, latter steel blue, almost bare; pleuron steel blue, light-grey pollinose and pilose on pteropleuron and sternopleuron; legs dark-brown, lighter at tips of femora and bases of tarsi; wing almost reaching tip of abdomen, clear except infuscated subcostal cell.

Abdomen: Broadly petiolate, tergites with suboppressed sparse grey 
pile except pile erect on anterior tergites, shiny steel blue with following opaque black markings: broad band on $2 \mathrm{~d}, 3 \mathrm{~d}$, and 4 th, broadly interrupted on latter with narrow stripe between, 5 th with two transverse spots divided with narrow stripe.

Male: Unknown.

Types: Holotype $\&$ Castañer, P.R. Feb. 15-17, 69 Telford, Medina, Malaise trap (acc. no. 345); seven paratypes, one $\$$ same data; one $\%$ Cayey, P.R.-Henry Barracks, 4-20-69. S. Medina Gaud, Malaise trap; two o Mayagüez, P.R. Feb. 4, 1969. Telford, Medina, Malaise trap; two ㅇ Río Piedras, P.R. 10-23-69, Telford, Medina, Malaise trap; ㅇ Arecibo, Cambalache Forest, Feb. 12-13-69, Telford, Medina, Malaise trap. The type and four paratypes are deposited in the M. T. James Collection,

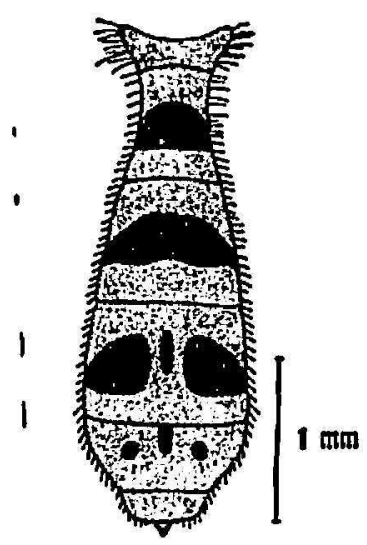

Fic. 3.-Dorsal abdominal aspect of holotype female of Baccha (Baccha) marlorelli n. sp.

WSU, one paratype is in the CNC, and the remaining paratypes are in the Collection at Río Piedras.

This species is named for Dr. L. F. Martorell, well known Puerto Rican entomologist and naturalist.

\section{Baccha (Ocyptamus) medina new species (Fig. 4)}

This is a shiny, bluish-black species, abdomen with subparallel sides and with four short, diagonal lateral yellow rectangular markings; portions of pleuron, humerus and lateral portions of 1st abdominal tergite grey pollinose. The affinity of this species is uncertain. It belongs to Ocyptamus, having the white pilose collar along the anterior margin of the mesonotum, but lacks the strap-like medial projection of the 2nd antennal segment. It keys to latiusculus and dimidiatus in Curran (29) and to the gastrostactus, fascipennis, lemur and cylindrica group in Hull (56). Length of body of holotype, $7.5 \mathrm{~mm}$. 
Female: Head: Face yellowish grey, prominently tuberculate, broad light-brown stripe covers tubercle and extends to antenna; latter brown, 3rd segment much longer than combined basal segments; front light-brown immediately above antenna with a dark shiny spot in center, broad shiny black triangle extends past ocelli to occiput, lower $2 / 3$ of front bordered with yellowish grey.

Thorax: Shiny steel blue, sparsely white pilose with following grey pollinose markings; humerus, notopleuron, posterior callus, posterior portion of pteropleuron and upper portion of sternopleuron. Wing extending slightly beyond abdomen, lightly uniformly infuscated except brown subcostal cell darker. Pro-leg and meso-legs light brown, meta-leg darker brown.

Abdomen: Shiny dark blue, subspatulate. Lateral anterior corner of 1st tergite greatly swollen, yellowish-grey with prominent yellow-white

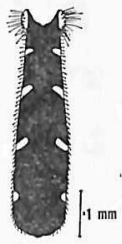

Fig. 4.-Dorsal abdominal aspect of holotype female of Baccha (Ocyptamus) medina n. sp.

pile; 2nd tergite about $1 / 4$ longer than 3rd or 4 th tergite with scattered short black pile and longer white pile anteriorly, lateral abbreviated rectangular spot about midway of tergite; 3rd and 4th tergites similar except shorter, lateral marking transverse and longer, situated more anterior of tergite; 5 th tergite with reduced lateral yellow spot.

Types: Holotype + , Arecibo, Cambalache Forest, P.R. 11/15-17/69. Telford, Medina, Malaise trap (ace. no. 348), deposited in the M. T. James Collection, WSU.

This species is named in honor of Mr. Silverio Medina Gaud, Dipterist, who significantly contributed to this investigation.

\section{Baccha (Baccha) neoparvicornis new species (Fig. 5)}

This species superficially resembles parvicornis Loew but is distinguished from it by the brownish mesonotum. With rare exceptions parvicornis lacks an apical wing spot. In neoparvicornis it is absent. Length of body of holotype, $6.5 \mathrm{~mm}$. 
Male: Head: Face yellow, broadly tuberculate, sparse black pile on upper area; antenna darker yellow, 3rd segment brownish at tip. Front yellowish-brown with sparse black pile, round shiny black-brown spot immediately above antennal base, ocellar triangle dark brown.

Thorax: Mesonotal disc dark-brown; lateral margin of mesonotum, pleuron, scutellum and legs yellow. Wing lightly infuscated, darker along costal margin. Subcostal cell brown.

Abdomen: Subparallel, light-brown with darker brown markings as follows: 1st tergite all but extreme lateral margin which is dull yellow; 2nd tergite broadly at base, narrowest medially and extending to terminal brown ring; 3rd tergite terminal ring and narrow median line; 4th and 5th, similar except brown at posterior areas, broader near margins and projecting anteriorly. Prominent blackish-brown pile on lateral tergite.

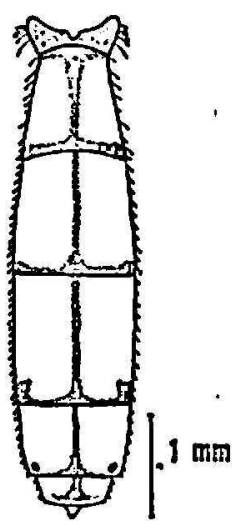

Fra. 5.-Dorsal abdominal aspect of allotype female of Baccha (Baccha) neoparvicornis $\mathrm{n} . \mathrm{sp}$.

Female: Similar to $\sigma^{7}$ except brown abdominal markings less prominent, mesonotal disc with golden pollen obscuring ground color and with faint black vitta extending posteriorly to $3 / 4$ length of notum. Scutellum yellow.

Types: Holotype ơ , Arecibo, Cambalache Forest, P.R. Feb. 15-17, 1969. Telford, Medina, Malaise trap (acc. no. 346) and Allotype $\$$ Cayey, Henry Barracks, P.R. 4-20-21, 1969. S. Medina Gaud, Malaise trap, deposited in the M. T. James Collection, WSU. Paratypes, one \&, one $\sigma^{7}$ Cayey, Henry Barracks P.R. Mar. 12-19, 1969. S. Medina Gaud, Malaise trap, in the collection at Río Piedras.

There is some variation in the abdominal and thoracic coloration. In the allotype $\%$ and in the $\sigma^{\top}$ and $\%$ paratypes, the mesonotum is golden pollinose.

\section{Baccha (Calostigma) ornatipes Curran}

Baccha ornatipes Curran 1927: 3, (15).

Curran (15) described this species from a single or from Cayey. Mr. Medina collected a $\$$ with a Malaise trap, also from Cayey. 


\section{Baccha (Baccha) parvicornis Loew (Fig. 7)}

Baccha parvicornis Loew 1861: 41, (65).

Wolcott (107) recorded this species from Cabo Rojo and Río Piedras. He suggested that the larvae prey upon fulgorids, white flies and mealybugs. Mr. Medina reared this species from guava heavily infested with the aleyrodid, Metaleurodicus minimus (Qt.) from Isabela. This species is quite common. I have seen specimens from Cayey, El Verde-Caribbean National Forest, Proyecto Vázquez, Río Piedras, Arecibo, Gurabo, Castañer, Corozal, and San Juan. In the Mayagüez collection there are specimens from Caguas, Mayagüez and Luquillo.

\section{Baccha (Baccha) rica Curran}

Baccha rica Curran 1939b: 6, (28).

Maldonado and Navarro (72) recorded this species from Mayagüez
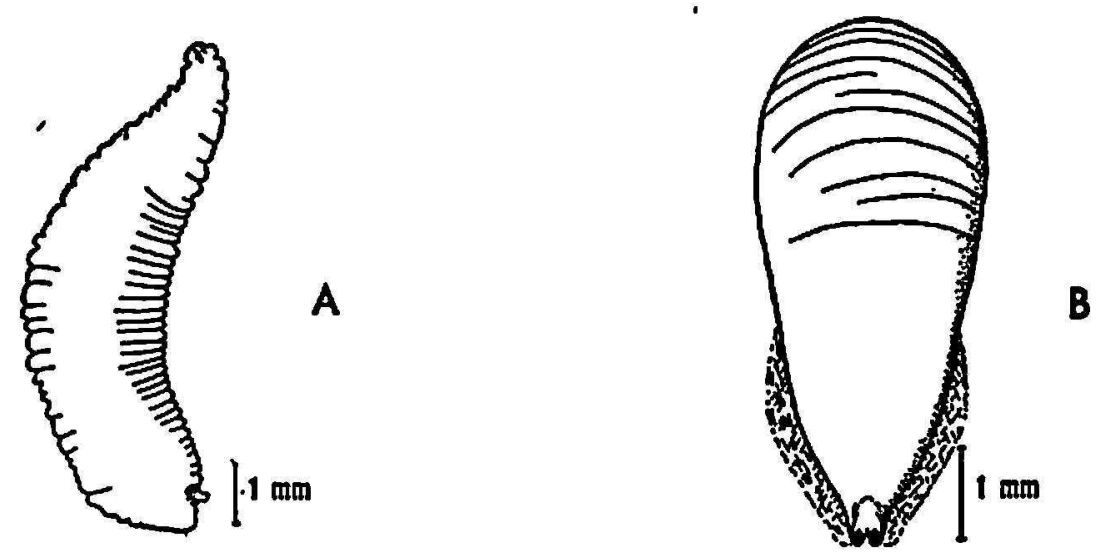

FIG. 6.-Baccha (Baccha) parvicornis Loew; A, Third instar larva observed feeding on aleyrodids (Melaleurodicus minimus (Qt.)); B, dorsal aspect of puparium.

(USNM). I examined a damaged $\sigma^{7}$ from Corozal loaned me by the AMNH.

\section{Baccha (Ocyptamus) vockerothi new species (Fig. 7)}

This is a slender, shiny brown species with infuscated wings; face, basal half of femora and sternopleuron, yellow grey. It has the anterior prothoracic collar of white pile characteristic of Ocyptamus. It appears related to fuscipennis Say but is smaller, the wing pattern less pronounced and the abdomen less broadened. Length of body of holotype, $8 \mathrm{~mm}$.

Male: Head: Face grey-yellow with short black pile, tuberculate, epistoma retreating, light-brown laterally. Front black pilose, ground color shiny steel blue except grey-yellow along anterior margin; 3rd antennal segment dark-brown, longer than basal segments combined, latter lighterbrown. 
Thorax: Notum shiny violaceous-brown with spare, short grey and black pile except collar of long white pile along anterior margin. Scutellum lighter brown with sparse grey and white pile. Pteropleuron grey-yellow with sparse grey and black pile, remainder of pleuron light brown, almost bare. Legs light-brown except yellow-grey on basal half of all femora. Wings almost reaching tip of abdomen, broadly infuscated along all veins, except in axillary region. The subcostal cell entirely infuscated as are broad areas beyond discal cell and terminal portion of cell $\mathbf{R}_{\mathbf{4}}$.

Abdomen: Petiolate, violaceous shiny-brown; first tergite with long white pile on edges, remaining tergites with sparse short black pile. Segments 2, 3 and 4 almost of equal length, 5 th half as long as 4 th.

Female: Very similar to $\sigma^{7}$ except face is yellow, upper portion of mesopleuron pale-yellow and scutellum more brown.

Types: Holotype ơ Arecibo, Cambalache Forest, P.R. Feb. 12-15 '69

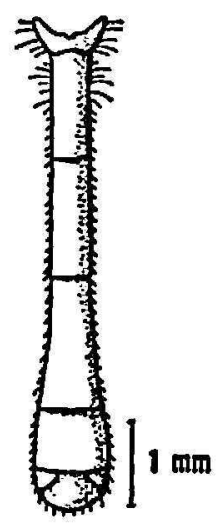

Fra. 7.-Dorsal abdominal aspect of holotype male of Baccha (Ocyptamus) vockerothi n. sp.

Telford, Medina, Malaise trap (acc. no. 247); allotype ㅇ Castañer, P.R. Feb. 15-17'69 Telford, Medina, Malaise trap. Paratypes: One $q$ same data as allotype; one $\%$, one $\sigma^{\top}$ same data as holotype. Holotype, allotype and one paratype deposited in the M. T. James Collection, WSU, one paratype each is deposited in the collection at Rio Piedras, and CNC.

This species is named in honor of Dr. J. R. Vockeroth.

\section{Genus Xanthandrus Verrall}

Xanthandrus Verrall 1901: 316 (96) (Type comptus Harris).

Melanostoma (Xanthandrus) Shannon 1922: 34, (88).

References: Curran (21), Fluke (41,42), and Hull (57).

The larvae are aphidophagous.

\section{KEY TO SPECIES}

Thorax brassy with brownish-yellow pile...........cubanus Fluke Thorax blue with sparse grey pile............... simplex (Loew) 


\section{Xanthandrus cubanus Fluke}

Xanthandrus cubana Fluke 1936: 63, (40).

Fluke recorded this species from Puerto Rico and Cuba. One headless specimen of a Xanthandrus, which may have been this species, labeled "Yauco viii-9-1934" was examined in the Mayagüez collection. Fluke's $\sigma^{7}$ paratype (Las Mesas, Porto Rico, Dec. 22, 1929, A. G. Harley) was loaned me from AMNH.

\section{Xanthandrus simplex (Loew)}

Syrphus simplex Loew 1861: 40, (65).

One $q$ was examined labeled: "Arecibo, Cambalache Forest, reared in lab. Dec. 3, 1969. S. Medina Gaud." This specimen was compared with Loew's type from MCZ.

\section{Genus Parapenium Collin}

Parapenium Collin, 1952: 85, (9) (Type carbonaria Zett.).

Pipizella, authors, not Rondani.

Triglyphus, authors, not Loew.

References: Curran $(10,11)$ (Pipizella).

Although little is known of the biology of this group, the species apparently are aphidophagous.

\section{Parapenium banksi (Curran)}

Pipizella pulchella banksi (Curran) 1921: 349, (10).

This U.S. species was collected from Corozal, Lajas, Cayey, Gurabo, Fortuna, and Isabela, and apparently is a new record for the island.

\section{Genus Ornidia Lepeletier and Serville}

Ornidia Lepeletier and Serville 1828: 786 (64) (Type obesus Fabricius).

References: Williston (101); Curran (19).

The immature stages are poorly known. Sack (84) recorded the larvae of obesa (F.) from Paraguay, inhabiting decaying fruits and human excrement.

\section{Ornidia obesa (Fabricius)}

Syrphus obesus Fabricius 1775: 763, (34).

This is a relatively common species. I have seen specimens from a number of localities in both Río Piedras and Mayagüez collections.

\section{Genus Volucella Geoffroy}

Volucella Geoffrey 1762: 540 (47) (Type pellucens Linnaeus). Pterocera Meigen 1803: 275, (74).

Temnocera Lepeletier and Serville 1828: 786, (64). 
Phalacromya Rondani 1848: 67, (80).

Glaurotricha Thomson 1869: 493, (95).

Atemnocera Bigot 1882: 114, (6).

Camerania Giglio-Tos 1892: 45, (48).

References: Williston (101,103); Curran (14,15,16,19,24,26,27,30).

The larvae of some species inhabit nests of certain social hymenoptera while others live in cacti. An excellent two-volume classical monograph on the genus, by Kunckel d'Herculais' (60), should be consulted for information on the anatomy and descriptions of immature stages.

\section{KEY TO SPECIES}

1. Large (18-20 mm.), mostly black.........esuriens (Fabricius) Smaller (6-8 mm.), yellow, yellow and black or brownish and violaceous................................ 2

2. Pleuron with yellow spots; scutellum with mass of long black pile... . 3 Pleuron unicolorous; abdominal tergites yellow with black or violaceous spots; scutellum with pre-apical depression...........4

3. Femur and tibia black................... pusilla Macquart Femur and tibia brown................. unipunctata Curran

4. Abdominal tergites yellow with black spots......pallens Wiedemann Abdomen with posterior margin of 2nd tergite, and tergites 3 and 4 unicolorous, violaceous..................tricincta Bigot

\section{Volucella esuriens (Fabricius)}

Syrphus esuriens Fabricius 1794: 281 (37); Curran 1953: 8, (30). Volucella rica Curran 1939a: 6, (27).

I have seen no specimens of this distinctive species from Puerto Rico but it undoubtedly occurs there. Wolcott (107) credits von Roeder as having determined it from Puerto Rican material collected by Dr. Gundlach.

\section{Volucella eugenia Williston}

Volucella eugenia Williston 1887: 139 (101); Curran 1953: 5, (30). Volucella ingenia Curran 1930c: 4, (19).

I have not included this species in my key because I am not certain that it occurs in Puerto Rico. Wolcott (107) did not record it. However, Curran (16) included eugenia in his key to the species of Puerto Rico but omitted reference to locality data. This species has been recorded from the Bahamas, Jamaica and Cuba (Fluke 45,46).

\section{Volucella pallens Wiedemann}

Volucella pallens Wiedemann 1830: 204, (100).

Volucella testacea Rondani 1848: 1, (80).

Volucella sexpunctata Loew 1861: 38, (65). 
I examined a number of specimens in the Mayagüez collection from Aibonito, Aguadilla, Río Piedras, Mayagüez and Ponce. The collection at Río Piedras contains specimens from El Verde-Caribbean National Forest, Cayey, Río Piedras, Barranquitas, and Arecibo.

\section{Volucella pusilla Macquart}

Volucella pusilla Macquart 1842: 21, (70).

Although I saw no specimens from Puerto Rico and Curran (16) did not list it, Wolcott (107) stated " . . originally described from Cuba, was listed from Puerto Rico by Dr. Gundlach, having been identified by Herr von Roeder."

\section{Volucella tricincta Bigot}

Volucella tricincta Bigot 1875: 477, (4).

Kertész (59) lists "tricincta" Bigot and varians Bigot as synonyms of purpurifera Bigot. Fluke (46, p. 83) also lists tricincta as synonymous with purpurifera; on p. 87, however, he lists tricincta as a valid species as does Stone et al. (90). Seven specimens were examined from El Verde and Río Piedras. Wolcott (107) recorded it from Mayagüez and Bayamón. One $q$, USNM, was collected at light from Las Marías.

\section{Volucella unipunctata Curran}

Volucella unipunctata Curran 1926b: 63, (14).

Graptomyza horvathi Szilády 1926: 610, (92) (NEW SYNONYM).

The badly damaged type ( $q$ ) of horvathi was loaned to me through the courtesy of Dr. H. Frankhanel, Deutsches Entomologisches Institut, Berlin. This specimen was compared with Puerto Rican material collected by Mr. Medina and me, as well as with other material identified as horvathi by C. T. Green and Dr. W. W. Wirth, and as unipunctata by Dr. H. V. Weems. I believe all to be conspecific.

A large series of this species was reared from the cactus Opuntia dilenii by Mr. Medina from Desecheo Island (west of Puerto Rico) and Icacos Key (east of Puerto Rico) in 1968. Additional records include San Germán, Mona Island (west of Puerto Rico), Proyecto Vázquez, Guánica and Caja de Muertos Island (south of Puerto Rico). The Mayagüez collection contains specimens from Yauco and Adjuntas. I examined material in the USNM from Mona Island and Guánica and, for verification, compared this material with Curran's paratype of unipunctata.

\section{Genus Crepidomyia Shannon}

Crepidomyia Shannon 1926: 47 (89) (Type tricrepis Shannon = genuina (Williston).)

References: Shannon (89); Hull (57) and Fluke (43). 


\section{Crepidomyia genuina Williston}

Xylota genuina Williston 1888: 284, (102).

Crepidomyia tricrepis Shannon 1926: 47, (89).

I have seen no specimens of this species from Puerto Rico. Dr. Vockeroth (in litt.) stated that one $\%$ from Puerto Rico (EI Yunque Sta. Luquillo Forest 10-16 VII 1969, H. and A. Howden) is deposited in the CNC. He also suggested $C$. darlingtoni Hull might be a synonym.

\section{Genus Neplas Porter}

Planes Rondani 1863: 9, (82) (preoc.). Neplas Porter 1927: 96, (77) (Type vagans Wiedemann).

References: Williston (101); Shannon (89); Curran (24,29), and Hull (57).

The larvae probably feed upon decomposing organic matter.

\section{Neplas pachymera (Loew)}

Xylota pachymera Loew 1866a: 162, (67).

I have seen no Puerto Rican specimens. However, Wolcott (107) stated that this species was collected from the island by Dr. Gundlach and identified by Victor Von Roeder. Fluke $(45,46)$ recorded it from Cuba and Puerto Rico.

\section{Genus Meromacrus Rondani}

Plagiocera Macquart 1842: 59, (70) (preoc.).

Meromacrus Rondani 1848: 70, (80) (Type ghiliani Rondani).

Pleroptila Loew 1866a: 165, (67).

References: Williston (101,106); Sack (83); Curran $(24,25)$ and Hull (52,57).

The larvae are little known but probably feed upon decomposing organic matter.

\section{KEY TO SPECIES}

Length 10-13 mm.; tomentose markings on mesontal suture long and narrow.............................flukei Curran

Length 17-19 mm.; tomentose marking on mesontal suture restricted to lateral spots.............................. (Drury)

\section{Meromacrus cinctus (Drury)}

Musca cincta Drury 1770: 109, (32).

Syrphus pinguis Fabricius 1775: 763, (34).

Milesia ania Walker 1849: 54, (97).

Curran (16) and Wolcott (107) recorded this species from Hormigueros, 
Río Piedras, Jayuya, Adjuntas, El Yunque and El Verde-Caribbean National Forest. Additional records were obtained, mostly by Malaise and black light traps, from Cayey, El Verde, Villalba and Mameyes. The Mayaguiez collection contains specimens from Río Piedras, El Yunque, Mayagüez and Jayuya.

\section{Meromacrus flukei Curran}

Meromacrus pratorum Williston (not Fabricius) 1896b: 346, (106).

Meromacrus flukei Curran 1936a: 3, (25).

This species has been recorded from Puerto Rico as pratorum Fabricius by Curran (16) and Wolcott (107). However, Curran (25) later believed flukei to be distinct. $M$. pratorum occurs in South America. While the types of flukei were collected from St. Vincent and St. Thomas, this species was not represented in the collections at Río Piedras or Mayagüez.

\section{Genus Eristalis Latreille}

Tubifera Meigen, 1800: 34, (73), suppressed by I.C.Z.N. 1963.

Elophilus Meigen 1803: 274, (74).

Helophilus Leach in Brewster 1817: 159, (8). Elophilus also should be suppressed and Helophilus amended because of possible confusion with Helophilus Meigen (Stone et al., 1965), (90).

Eristalis Latreille 1804: 194, (62) (Type tenax Linneaus).

Eristaloides Rondani 1844: 453, (79).

Eristalomya Rondani 1857: 38, (81).

References: Williston $(101,102)$; Osburn (75); Hull (49); Curran $(22,24)$;

Bean (3) and Telford $(93,94)$.

The larvae of this group are the common distinctive "rat-tailed" maggots. Their presence in water supplies is an indication of pollution. They are found usually in decomposing plant or animal material.

\section{KEY TO SPECIES}

1. Apical half of wing brown on costal portion... hortorum (Fabricius) Wings hyaline or at most lightly infuscated.............. 2

2. Posterior tibia with definite row of brownish pile on outer margin, becoming lighter at base; foreleg usually reddish vinetorum (Fabricius)

Posterior tibia lacking definite row of pile; foreleg usually dark-brown

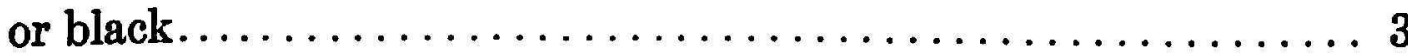

3. Pteropleural pile entirely or mostly black.........atrimanus Loew Pteropleural pile pale......................... 4

4. Scutellum with at most a few scattered black hairs albifrons albifrons Wiedemann

Scutellum with predominantly black pile............... 5 
5. Frontal pile partially black; ash-gray prescutellar fascia present agrorum agromum (Fabricius)

Frontal pile pale; no prescutellar fascia.........pusio Wiedemann

\section{Eristalis agrorum agrorum (Fabricius)}

Syrphus agrorum Fabricius 1787: 335, (36).

Eristalis cubensis Macquart 1842: 42, (70).

Eristalis agrorum agrorum Fabricius, Telford 1949: 39, (93), 1970: 1204, (94).

This species is quite rare. Curran (16) recorded a single female from Manati. An additional specimen from Río Piedras is in the Mayagüez collection.

\section{Eristalis albifrons albifrons Wiedemann}

Eristalis albifrons Wiedemann 1830: 189, (100).

Eristalis albiceps Macquart 1842: 56, (70).

Eristalis seniculus Loew 1866a: 168, (67).

Eristalis albifrons albifrons Wiedemann, Telford 1949: 39, (93), 1970: 1204, (94).

Curran (16) and Wolcott (107) recorded this species from El Yunque, Loiza and Pueblo Viejo. Six specimens are in the Río Piedras collection from Río Piedras, Santurce and Yauco. An additional specimen from Río Piedras is in the Mayagüez collection.

\section{Eristalis atrimanus Loew}

Eristalis atrimanus Loew 1866a: 167, (67).

Curran (16) and Wolcott (107) recorded this species from several localities. An additional specimen was recovered from a Malaise trap at El Verde.

\section{Eristalis hortorum (Fabricius)}

Syrphus hortorum Fabricius 1775: 764, (34).

Musca surinamensis DeGeer 1776: 145, (31).

Wolcott (107) recorded this species from St. Thomas, and from Dorado, Ponce and Mayagüez, Puerto Rico. One unlabelled specimen, presumably from Puerto Rico, is in the Río Piedras collection. In addition, three specimens are in the Mayagüez collection from Coamo, Mayagüez and Río Piedras.

\section{Eristalis pusio Wiedemann}

Eristalis pusio Wiedemann 1830: 192, (100).

Although Wolcott $(107)$ and Fluke $(45,46)$ recorded this species from the island, no specimens were examined from Puerto Rico. 


\section{Eristalis vinetorum (Fabricius)}

Syrphus vinetorum Fabricius 1798: 526, (38).

Eristalis trifasciatus Say 1829: 165, (86).

Eristalis uvarum Walker 1849: 623, (97).

Eristalis soulouguensis Bigot 1880: 228, (5).

This is the most common Eristalis on the island and is well represented in the Río Piedras and Mayagüez collections.

\section{SUMMARY}

This paper presents results of a taxonomic investigation of the family Syrphidae of the order Diptera in Puerto Rico. A total of 58 species included in 11 genera are presently recorded as a result of synonymy, new records, and descriptions of the following four new species: Baccha (Baccha) martorelli, Baccha (Ocyptamus) medina, Baccha (Baccha) neoparvicornis and Baccha (Ocyptamus) vockerothi. Keys are given for the identification of the reported genera and for most of the recorded species.

\section{RESUMEN}

Este trabajo comprende un estudio taxonómico de la familia Syrphidae del orden Diptera en Puerto Rico. Se informa un total de 58 especies de sírfidos que pertenecen a 11 géneros, resultado de sinonimias, nuevos records y la descripción de 4 nuevas especies, a saber: Baccha (Baccha) martorelli, Baccha (Ocyptamus) medina, Baccha (Baccha) neoparvicornis y Baccha (Ocyptamus) vockerothi. Se incluyen varias claves, unas para la identificación de los géneros y otras para la mayoría de la especies informadas en este trabajo.

\section{LITERATURE CITED}

1. Ashmead, W. H., Orange insects, Jacksonville, Fla., 78 pp. 1880.

2. Austen, E. E., Descriptions of new species of dipterous insects of the family Syrphidae in the collection of the British Museum, with notes on species described by the late Francis Walker, Zool. Soc. London, Proc. Part I. Bacchini and Brachyopini, 1893: 132-64, 1893.

3. Bean, J. L., A study of male hypopygia of the species of Tubifera (Syrphidae, Diptera) that occur north of Mexico, Can. Entom. 81 (6): 140-52, 1949.

4. Bigot, J. M. F., Diptères nouveaux ou peu connus. Soc. Entomol. de France, Ann. Ser. 5, 5: 469-82, 1875.

5. - Diptères nouveaux ou peu connus, Soc. Entomol. de France. Ann. Ser. 5, 10: 213-30, 1880.

6. - Diagnoses de genres et espèces inéditis de Syrphides, Soc. Entom. de France, Ser. 6, 2 (Bul.) CXIV, 1882.

7. Diptères nouveaux on peu connus. Soc. Entomol. de France, Ser. 6, 3: 315-56, 1883.

8. Brewster, D., ed. The Edinburgh Encyclopedia 12: 1-376, pls., 1817.

9. Collin, J. E. On the subdivisions of the genus Pipizella Rnd. and on additional British species (Diptera, Syrphidae). Brit. Entomol. Soc. J. 4: 85-8, 1952.

10. Curran, C. H., Revision of the Pipiza group of the family Syrphidae (flowerflies) from north of Mexico, Calif. Acad. Sci. Proc. Ser. 4, 11: 345-93, 1921. 
11. - Notes on the genus Pipizella Rondani with descriptions of new species (Diptera, Syrphidae) Amer. Entomol. Soc. Trans. 49: 339-45, 1924.

12. - Some syrphid synonymy (Diptera). Canad. Entomol. 57 (12): 307, 1925.

13. - New Diptera from Jamaica, in C.C. Gowdey's Catalogus insectorum Jamaicensis, Appendix. Jamaica Dept. Agri. Bul. 4: 102-14, 1926a.

14. - Partial synopsis of American species of Volucella with notes on Wiedemann's types, Entomol. Soc. Amer. Ann. 19: 50-66, 1926b.

15. - New Neotropical and Oriental Diptera in the American Museum of Natural History, Amer. Mus. Novitates No. 245 : 1-9, 1927.

16. - Insects of Porto Rico and the Virgin Islands. Diptera or two-winged flies, Pt. 1, pp. 1-118, 39 figs. Scientific Survey of Puerto Rico and The Virgin Islands. In New York Academy of Sciences, (q.v.) Vol. 11, New York, N.Y., 1928.

17. - New species of Diptera belonging to the genus Baccha Fabricius (Syrphidae), Amer. Mus. Novitates No. 403: 1-16, 1930a.

18. - New Diptera belonging to the genus Mesogramma Loew (Syrphidae), Amer. Mus. Novitates No. 405: 1-14, $1930 \mathrm{~b}$.

19. - New species of Volucellinae from America (Syrphidae, Diptera), Amer. Mus. Novitates No. $413: 1-23,1930 c$.

20. - , Report on the Diptera collected at the Station for the Study of Insects, Harriman Interstate Park, N.Y., Amer. Mus. Nat. Hist. Bull. 61: 21-115 $1930 \mathrm{~d}$.

21. - New Syrphidae from Central America and the West Indies, Amer. Mus. Novitates No. 416: 1-11, 1930e.

22. - New Species of Eristalinae with notes (Syrphidae, Diptera), Amer. Mus. Novitates No. 411 : 1-27, 1930 f.

23. - New American Syrphidae (Diptera), with notes, Amer. Mus. Novitates Novitates No. 519: 1-19, 1932.

24. - The Diptera of Kartabo, Bartica District, British Guiana, with descriptions of new species from other British Guiana localities, Amer. Mus. Nat. Hist. Bull. 66: 287-532, 1934.

25. - Three new species of Meromacrus (Diptera, Syrphidae), Amer. Mus. Novitates No. 834: 1-5, 1936a.

26. - - New Neotropical Syrphidae (Diptera), Amer. Mus. Novitates No. 882: 1-17, 1936b.

27. - Synopsis of the American species of Volucella (Syrphidae:Diptera). Part I. Table of species, Amer. Mus. Novitates No. 1027: 1-7, 1939a.

28. —-, New Neotropical Baccha Fabricius (Syrphidae: Diptera), Amer. Mus. Novitates No. 1041: 1-12, 1939 b.

29. - New American Syrphidae, Amer. Mus. Nat. Hist. Bull. 78: 243-304, 1941.

30. - Notes and descriptions of some Mydaidae and Syrphidae, Amer. Mus. Novitates No. 1645: 1-15, 1953.

31. DeGeer, C., Mémoires pour servir a l'histoire des Insectes, Stockholm, Sweden 6: 1-523, 1776.

32. Drury, D., Illustrations of natural history (Exotic insects), London, England 1: 1-130, 1770.

33. Enderlein, G., Beiträge zur Kenntnis der Syrphiden, Gesell. Naturf. Freunde, Berlin, Sitzberg. 1937 : 192-237, 1938.

34. Fabricius, J. C., Systema entomologiae . . . Flensburgi et Lipsiae, 832 p. 1775.

35. - Species insectorum exhibentes eorum differentias specificas, synonyma, auctorum, loca natalia, metamorphosin, Hamburgi et Kilonii, 2: 1-517, 1781. 
36. - Mantissa insectorum sistens species nuper detectas, Hafniae, 2: 1-382, 1787.

37. - Entomologia systematica emendata et aucta. Hafniae, 4: 1-472, 1794.

38. — Supplementum entomologiae systematicae, Hafniae, 572 p., 1798.

39. - Systema antiliatorum secundum ordines, genera, species, Brunsvigae, 373 p., 1805.

40. Fluke, C. L., New Syrphidae (Diptera) from Brazil and Cuba, Kans. Entomol. Soc. J. 9: 59-64, 1936.

41. - New South American Syrphidae (Diptera), Amer. Mus. Novitates No. 941: 1-14, 1937.

42. - - Revision of the Neotropical Syrphini related to Syrphus (Diptera, Syrphidae), Amer. Mus. Novitates No. 1201: 1-24, 1942.

43. - Some new Tropical syrphid flies with notes on others, Acta Zool. Lill. 9: 439-54, 1950.

44. - - Some syrphid fly synonymy, Entomol. News 64: 208-9, 1953.

45. - Catalog of the family Syrphidae in the Neotropical Region, Rev. Brasil Entomol. 6: 193-268, 1956.

46. - - Catalog of the family Syrphidae in the Neotropical Region, Rev. Brasil Entomol. 7: 1-181, 1957.

47. Geoffroy, E. L., Histoire abrégée des insectes qui se trouvent aux environs de Paris, 2: 1-690, 1762.

48. Giglio-Tos, E., Ditteri del Messico Pt. 1, Torino, Italy, 72pp., 1892.

49. Hull, F. M., A review of the genus Eristalis Latreille in North America, Ohio J. Sci. 25: 11-45, 285-312, 1925.

50. - Some new species of Syrphidae, Wash. Acad. Sci. J. 30 (10) : 432-34, 1940.

51. - Some new species of Syrphidae from South America, Wash. Acad. Sci. J. 31: 311-15, 1941.

52. - The flies of the genus Meromacrus (Syrphidae), Amer. Mus. Novitates No. 1200: 1-10, 1942.

53. - The genus Mesogramma, Entomol. Amer. 23 (1): 1-40, 1943a.

54. - The new world species of the genus Baccha, Entomol. Amer. 23 (1): 42-99, 1943b.

55. —- Studies on syrphid flies in the Museum of Comparative Zoology, Psyche 51: 22-45, 1944.

56. —, The genus Baccha from the New World, Entomol. Amer. $27(3,4): 89-291$, 1949a.

57. —- The morphology and inter-relationship of the genera of the syrphid flies, recent and fossil, Zool. Soc. London Trans. 26: 257-408, $1949 \mathrm{~b}$.

58. Jaennicke, F., Neue exotische Dipteren, Senckenb. Naturf. Gesell. Abh. 6: 311-408, 1867.

59. Kertész, K., Catalogus dipterorum hucusque descriptorum, Lipsiae, 7 : 1-470, 1910.

60. Kunckel, d'Herculais, Recherches sur l'organization et le dévelopment des Volucelles, 2 vols. Paris, France, 1875.

61. Láska, P., On bionomy of aphidophagous Syrphidae, especially on the food ecology of larvae (Syrphidae, Diptera), Bohem. Centra. A-1: 321-44, 1959.

62. Latreille, P. A., Tableau méthodique des Insectes, pp. 129-200. In Société de Naturalistes et d'Aguiculteurs, Nouveau dictionnaire d'histoire naturelle, appliqué aux arts, principalement à l'agriculture et à l'économie rurale et domestique, vol. 23,1804 . 
63. Leach, W. E., In Brewster's, On the genera and species of eproboscideous insects, Edinburgh, Scotland, 20 p., 1817.

64. Lepeletier, A. L. M., Serville, J. G. A., and Guérin-Méneville, F. E., (1828) In Latreille's, Entomologie, ou histoire naturelle des Crustacés, des Arachnides et des Insectes, Paris, France 10: 1-833, 1825.

65. Loew, H., Diptera aliquot in insula Cuba collecta, Wien. Entom. Monatschr. 5: 33-43, 1861.

66. - Diptera Americae septentrionalis indigena, Centuria 3, Berlin. Ent. Ztschr. 7: 1-55, 1863.

67. - , Diptera Americae septentrionalis indigena, Centuria 6, Berlin Ent. Ztschr. (1865), 9: 127-86, 1866a.

68. - Diptera Americae septentrionalis indigena, Centuria 7, Berlin Ent. Ztschr. 10: $1-54,1866 \mathrm{~b}$.

69. - Diptera Americae septentrionalis indigena, Centuria 10, Berlin Ent. Ztschr. 16: 49-115, 1872.

70. Macquart, J., Diptères exotiques nouveaux ou peu connus, Paris, France, 2(2): 5-140, 1842.

71. - Diptères exotiques nouveaux ou peu connus, 4e supplément (part), Soe. des. Sci. de L'Agr. et des Arts. Lille, Mem. 1849, 309-465, 1850.

72. Maldonado Capriles, J., and Navarro, C. A., Additions and corrections to Wolcott's "Insects of Puerto Rico", Carib. Sci. J. 7(1,2): 45-64, 1967.

73. Meigen, J. W., Nouvelle classification des mouches a deux ailes (Diptera L.) d'après un plan nouveau, Paris, France, 40 p. 1800.

74. —_, Versuch einer neuen Gattungseinthelung der euröpaischen zweiflügeligen Insekten. Mag. f. Insekten. 2: 259-81, 1803.

75. Osburn, R. C., Studies in Syrphidae, 4. Species of Erislalis new to America, with notes on others, N.Y. Entomol. Soc. J. 23 : 139-45, 1915.

76. Osten Sacken, C. R., A list of the North American Syrphidae, Buffalo Soc. Nat. Sci. Bul. 3: 38-71, 1876.

77. Porter, C. E., Cambio de nombre genérico en la fam. Sírfidos, Rev. Chil. Hist. Nat. 31: 96, 1927.

78. Roeder, V. von., Dipteren von der Insel Portorico, Stettin Entom. Ztg. 46: 337-49, 1885.

79. Rondani, C., Ordinis dipterorum. Strips II. Muscidae Rndn., Athericera Lat. Mac. Zett. West Soc. Agr. Accad. Sci. Inst. Bologna, Nuovi Ann. Sci. Nat. Rend. Ser 2: 447-59, 1844.

80. —_ Esame di varie specie d'insette ditteri Brasiliani, Studi Ent. Turin, Italy 1: 63-112, 1848.

. 81. - Dipterologiae Italicae prodromus, Parma, Italy 2: 264 p., 1857.

82. - Dipterorum species et genera aliqua exotica, Arch. Zool. 1'Anat. Fis. 3 (1): 1-99, 1863

83. Sack, P., Die Gattungen Salpingogaster Schiner and Meromacrus Rondani. Zool. Jahr. 43: 235-72, 1920.

84. $\longrightarrow$ Dr. L. Zucher's Dipteren-ausbeute aus Paraguay: Syrphiden, Archiv., Naturg. 87 (A3): 127-49, 1921.

85. Say, T., Descriptions of dipterous insects of the United States, Acad. Nat. Sci. Phil. J. 3: 9-54, 73-104, 1823.

86. - Descriptions of North American dipterous insects, Acad. Nat. Sci. Phil. J. (1829-1830) 6: 149-78, 1829.

87. Schiner, I. R., Diptera (Art. 1), 388 p. In Reise der Österrreichischen Fregatte Novara. Zool., Vol. 2. Abst. 1B, Wein, 1868. 
88. Shannon, R. C., A reclassification of the subfamilies and genera of the North American Syrphidae, Brooklyn Entomol. Soc. Bull. 17: 30-43, 1922.

89. - Review of the American xylotine syrphid-flies, U.S. Natl. Mus. Proc. 69(9): 1-52, 1926.

90. Stone, A. et al., A catalog of the Diptera of America north of Mexico, USDA Agr. Handbook, 276, 1696p., 1965.

91. Sundby, R. A., A comparative study of the efficiency of three predatory insects, Coccinella seplempunctala L., Chrysopa carnea St. and Syrphus ribesii L. at two different temperatures, Entomophaga $11: 395-404,1966$.

92. Szilády, Z., Dipterenstudien, Mus. Natl. Hung. Ann. 24: 586-611, 1926.

93. Telford, H. S., Summaries of Ph.D. Theses, Univ. of Minn., 4: 35-44, 1949.

94. - Eristalis (Diptera: Syrphidae) from America north of Mexico, Entomol. Soc. Amer. Annals 63(5): 1,201-10, 1970.

95. Thomson, C. G., Diptera, Species nova descripsit. In K. Svenska VetenskapsAkademien, Kongliga svenska fregatten Augenies resa omkring jorden Pt. 2: Zooloegie Insekter 617p., Stockholm, Sweden, "1868”, 1869.

96. Verrall, G. H., Platypezidae, Pipunculidae and Syrphidae of Great Britain, 8: 1-691 In (G. H. Verrall, ed.) British Flies, 1901.

97. Walker, F., List of the specimens of dipterous insects in the collection of the British Museum, 3: 485-687, 1849.

98. - Diptera 1:157-253, 253-414. In (Saunders, W.W., Ed.) Insecta Saundersiana (q.v.) "1856", 1852.

99. —- Characters of undescribed Diptera in the collection of W. E. Saunders, Entomol. Soc. London Trans. n. ser. 4: 119-57, 1857.

100. Wiedemann, C. R. W., Aussereuropäische zweiflügelige Insekten., Hamm, 2: $1-684,1830$.

101. Williston, S. W., Synopsis of the North American Syrphidae, U.S. Natl. Mus. Bull. 31: 1-335, 1887 (1886).

102. - Diptera Brasiliana, ab. H. H. Smith collecta, Part. I. Statiomyidae, Syrphidae, Entomol. Soc. Phil. Trans. 15: 243-92, 1888.

103. - Family Syrphidae, In F. D. Godman, and O. Salvin, (eds.) Biol. Cent.Amer. Zool. Insecta Diptera, London, England 3: 1-127, 1891.

104. - The North American Psychodidae, Entomol. News, 4: 113-4, 1893.

105. - Manual of the families and genera of North American Diptera, ed. 2, New Haven, Conn. 167 p., $1896 a$.

106. - On the Diptera of St. Vincent (West Indies), Entomol. Soc. London Trans. 1896: 253-446, $1896 \mathrm{~b}$.

107. Wolcott, G. N., The insects of Puerto Rico, Univ. P.R. J. Agr. 32: 1-975, 1948. 108. Wulp, F. M. van der, Amerikaanische Diptera, Tijdschr. v. Ent. 26: 1-60, 1883, 